\title{
ISO 9001:2015 Adoption: A Multi-Country Empirical Research
}

\author{
Luis Miguel Ciravegna Martins da Fonseca ${ }^{1}(\mathbb{D})$, José Pedro Domingues ${ }^{1}$ (iD), \\ Pilar Baylina Machado² (iD, Deane Harder $^{3}$ (iD \\ ${ }^{1}$ School of Egineering Polytchnic of Porto (Portugal) \\ ${ }^{2} S$ chool of Health (Portugal) \\ ${ }^{3}$ Business School, Bern University of Applied Sciences (Switzerland) \\ ImÆ@isep.iph.pt,jpd@isep.ipp.pt,.pbm@ess.ipp.pt,deane.harder@bfb.ch
}

Received: October 2018

Accepted: November 2018

\begin{abstract}
:
Purpose: This paper aims at identifying obstacles, benefits, leading practices and lessons learned in the transition/certification of the revised standard for quality management systems ISO 9001:2015 for organizations in various sectors, countries and spanning a range of sizes.
\end{abstract}

Design/methodology/approach: Based on literature review and inputs from experts in management systems certification, a quantitative survey was launched in Portugal, Romania, Switzerland, and Turkey in April 2018, addressed at quality and organizational managers and CEOs from ISO 9001:2015-certified organizations by certification bodies partners of the leading International Quality Network (IQNet). The answers were collected anonymously through an automated online database, until the end of April 2018. The overall response rate was $3.1 \%$, encompassing 222 organizations already certified according to ISO 9001:2015.

Findings: The surveyed organizations reported significant benefits from ISO 9001:2015 implementation. Only $3.9 \%$ of the respondents considered the 3-year transition period (from September 15, 2015, to September 15, 2018) as too short. The respondents' organizations attended ISO 9001:2015 training and seminars, and collected information from websites, newsletters, books and interpretation guides and directly from certification bodies. Some $(29.8 \%)$ relied on their own internal resources for the transition processes, while external consultants supported $22.7 \%$. The respondents considered the adoption of riskbased thinking the major difficulty to be overcome, but simultaneously as the major benefit to be realized. The alignment with other management systems, the increased top management commitment, the identification of risks and opportunities and the knowledge management were also reported as significant benefits.

The initial timing when organizations started working on the transition process and the activities carried out seem to differ between countries, while the adjustments performed to the existing management systems seem to differ by sector and size of the organization. The benefits attained by the organizations vary according to the perception regarding the information resources made available and organizations should be aware of the advantages of early planning. The organizations that rated the benefits of ISO 9001:2015 adoption higher considered the information resources as adequate and started working with ISO 9001:2015 at an earlier stage, while those that rated the benefits lower stated that the information resources were made available too late. The organizations that successfully managed the ISO 9001:2015 transition/certification process were the ones that attended ISO 9001:2015 training courses and seminars and got useful information from their certification body. 
This research highlights the relevance of the geographical context, of the organization size and the sector for successful adoption of ISO 9001:2015. The identification and promotion of resources that led to the highest benefits are worth pursuing. The replication of this study can add a time perspective and the assessment if these perceptions are expected to materialize into tangible results such as cost benefits and higher customer satisfaction.

Research limitations/implications: Due to the novelty of ISO 9001:2015, these results should be subjected to additional validation and longitudinal analyses. Although measures have been taken to minimize possible bias errors from both non-respondents', and respondents' subjectivity, these limitations of the survey methodology should be acknowledged.

Practical implications: The findings of this research provide standardization and certification bodies and quality management systems practitioners with leading practices in the implementation of ISO 9001:2015 and guidance for an efficient and effective transition/adoption.

Originality/value: This investigation contributes to the ISO 9001:2015 body of knowledge by mapping the transition/certification processes with a multi-country perspective. The results empirically validate the potential value of transitioning or adopting ISO 9001:2015 and give insights on the implementation methodologies, leading practices to follow, difficulties to overcome and benefits to realize, to maximize the success of ISO 9001:2015 adoption.

Keywords: ISO 9001:2015, quality management systems, certification, benefits, difficulties, methodologies

\section{To cite this article:}

Fonseca, L.M., Domingues, J.P., Baylina-Machado, P., \& Harder, D. (2019). ISO 9001:2015 adoption: A multicountry empirical research. Journal of Industrial Engineering and Management, 12(1), 27-50. https://doi.org/10.3926/jiem.2745

\section{Introduction}

Quality management is an economic issue; however, the drivers, as well as research perspectives, go far beyond. Literature reviews addressing ISO 9001 benefits (Tarí, Molina-Azorín \& Heras, 2012) and bibliometric studies on the intellectual structure of research in ISO 9000 (Hussain, Eskildsen \& Edgeman, 2018), converge on the conclusion that multidisciplinary fields, such as engineering, management sciences, social sciences, and behavioral sciences, contribute to the extensive existing research addressing quality management systems certification. Karapetrovic, Casadesús and Heras-Saizarbitoria (2010) acknowledged more than 30 empirical studies researching the impacts of ISO 9000 standards, while, more recently, Fonseca, Domingues, Machado and Calderón (2017) identified 101 scientific articles published between 2012 and April 2017 on this topic. According to Jain and Ahuja (2012), the ISO 9000 investigations focus on management issues, implementation, customer orientation, barriers, and advantage of certification. Considering the breadth and width of the scope of research on ISO 9000, analyzing the impact of a revision of the standard requires a multidimensional approach. Therefore, this study included organizations of different sizes, sectors and geographical location.

A standard should be a means to an end and, ultimately, prove to be beneficial. Based on a bibliometric study on the benefits of Management Systems Certification that analyzed 259 articles, from 699 authors, published in 132 scientific journals, from 1998 to April 2017, Fonseca, Domingues, Machado and Calderón (2017) concluded that a Quality Management System (QMS) certification generates benefits for the certified organizations, confirming previous research from other authors, e.g., Casadesús and Giménez (2000), Psomas and Fotopoulos (2009), Boiral (2012) and Tarí et al. (2012). These benefits can have both an internal and external scope, such as improved product quality and process performance, cost reductions, and higher quality awareness, leading to enhanced customer 
satisfaction and a stronger competitive position. However, there is some variation on the results achieved with QMS certification related to the organizational motivations (internal and external) and to the way the standard is interpreted and implemented (Fonseca, 2015b). Recent research has also been addressing the implementation of ISO 9001 in countries and regions not studied before (Bounabri, Oumri, Saad, Zerrouk \& Ibnlfassi, 2018). So, although there is ample evidence for the benefits of complying with ISO 9001, there are clear indications that the success of implementation is dependent on context factors not specified in the standard.

The perception of quality changes over time. With significant transformations driven by globalization, the move towards a more service-oriented economy, increasingly complex supply chains and the digital age, ISO had to ensure that the ISO 9001 quality management systems-requirements, international standard remained updated and adjusted to the current business environments. This led to the revision of ISO 9001:2015 published in September 2015, with the aim of ensuring the flexibility to respond to the rapid changes and the complexity of business dynamics, while ensuring that organizations that comply consistently with its requirements can deliver products and services that satisfy customers' needs and expectations and address the relevant statutory and regulatory requirements (Fonseca, 2015a). In short, ISO 9001 was revised to satisfy the requirements of supporting organizations with a QMS standard that reflects recent developments of business in general.

ISO released the ISO 9000 International Standards series in 1987. Since then, approximately 1,059 thousand organizations have implemented and certified their quality management systems (QMS) according to ISO 9001 requirements (ISO, 2018), assured by an audit and certified by an independent external certification body (CB). As of December 31, 2017, about $42 \%$ of the total ISO 9001 certificates have been issued according to the ISO 9001:2015 edition, while about 58\% were issued according to the ISO 9001:2008 edition (ISO, 2018). With this large number of lagging organizations and the need to shift to the latest edition of ISO 9001, guidance for a successful transition for practitioners is urgently required.

The revision of ISO 9001 affects all organizations willing to comply with this standard. Organizations that have been certified according to ISO 9001:2008 need to transition their existing QMS to the new edition by a successful transition audit to get re-certified before the end of the transition period, which ended September 15, 2018. After that date, ISO 9001:2008 (ISO, 2008) certificates will lose validity, even if the lifecycle of regular certifications may not have been concluded. Moreover, the International Accreditation Forum (IAF) passed a resolution stating that from March 15, 2018, CBs must conduct all ISO 9001 audits by the ISO 9001:2015 edition (IAF, 2017). The ISO Survey 2017 (ISO, 2018) indicated that as of December 31, 2017, only $42 \%$ of the ISO 9001 -certified organizations had successfully transitioned to ISO 9001:2015, with countries such as Japan boasting a transition rate of more than $65 \%$, while other countries like Italy reported a transition rate of only $24 \%$. With the validity of ISO 9001:2008 certifications ending soon, there is a strong need to investigate the ISO 9001:2015 transition process, namely the methodologies, the difficulties, the benefits, leading practices, and the overall lessons learned with these processes. As recognition of the need for action, this research can offer valuable insights for organizations that aim to implement and certify their QMS by ISO 9001:2015. To this avail, we present a first comprehensive study on the transition/certification process from ISO 9001:2008 to the revised ISO 9001:2015 from several countries and sectors, spanning a spectrum of sizes of organizations.

The next sections are organized as follows. Section 2 provides a brief literature review of ISO 9001:2015 implementation. Section 3 introduces the research methodology. The findings of the study are presented in Section 4. The last section 5 gives a systematic discussion of the results and the theoretical and practical implications as well as limitations and future research directions.

\section{Literature Review}

The first edition of the family of ISO 9000 standards for quality management systems (QMS) was published in 1987. During the introduction phase of ISO standardization, the main objectives of organizations seeking ISO 9001 series certification were to implement a documented quality system to facilitate the access to diversifying and more demanding global markets (Yahya \& Goh, 2001; Rodríguez-Escobar, Gonzalez-Benito \& Martínez-Lorente, 2006). Over time, the motivation evolved to improve process performance, streamline the overall documentation system, enhance customer satisfaction, improve business results and ensure company survival (Poksinska, Eklund, 
Jörn \& Jens, 2006; Han \& Chen, 2007; Singh, 2008; Clougherty \& Grajek, 2008; Cagnazzo, Taticchi \& Fuiano, 2010; Prajogo, 2011; Santos, Costa \& Leal, 2014; Chatzoglou, Chatzoudes \& Kipraios, 2015; Zimon, 2016). In summary, the motivations to seek an ISO 9001 series certification are typically both internal and external; however, the priorities (both in scope and depth) vary between different types of organizations (Sharma, 2005; Martínez-Costa, Martínez-Lorente \& Choi, 2008; Georgiev \& Georgiev, 2015), which can influence the way the ISO quality management system is implemented and the subsequent success of the implemented system (Casadesús \& Giménez, 2000; Martínez-Costa \& Martínez-Lorente, 2007).

The adoption and certification of a QMS support an organization's mission. The main leverage points are to achieve quality through cohesiveness and standardization of its processes (Terlaak, 2007), and to aim for maximum customer satisfaction, global recognition, and improved performance (Heras-Saizarbitoria, Arana \& Boiral, 2015). Corbett, Montes-Sancho and Kirsch (2005) tracked the financial performance of publicly traded ISO 9000-certified manufacturing firms in the United States from 1987 to 1997. They found that the decisions of firms to seek their first ISO 9000 certification were followed by significant abnormal improvements in financial performance. Lo, Yeung and Cheng (2009) found that economic and financial indicators improved one year after ISO 9000 implementation, based on a study of changes in 695 US-listed manufacturing firms prior and after ISO 9000 implementation. Data gathered by the Australian Bureau of Statistics (O’Neill, Sohal \& Teng, 2016) through a longitudinal panel indicated that quality management approaches of those firms had positive impacts on their financial performance. In a study of 27 Japanese manufacturing firms, Phan, Abdallah and Matsui (2011), confirmed a positive relationship between quality management practices and competitive performance. Jain \& Ahuja (2011), based on a study of published research addressing ISO 9000, posited that the investigations addressed mainly management and implementation issues, barriers, and the advantages of certification. Psomas and Fotopoulos (2009), based on another ISO 9000 meta-study, concluded that the findings suggest a positive impact of certification on the development of business excellence. More recently, Fonseca, Domingues, Machado et al. (2017) conducted a bibliometric study of scientific articles published between 1996 and April 2017 that also supports the view that QMS certification brings benefits for the certified organizations, which is in line with Boiral (2012) and Tarí et al. (2012). Overall, empirical research strongly supports the notion that the introduction of ISO 9000 yields tangible economic benefits for organizations.

ISO had reviewed its ISO 9001 standard in 2000 and in 2008. The next revision aimed to allow for an increased ISO 9001 flexibility while ensuring that organizations that meet its requirements can consistently provide products and services that satisfy their customers' needs and expectations and meet the relevant statutory and regulatory requirements. ISO reviewed the ISO 9001:2008 International Standard leading to the publication of ISO 9001:2015 on September 15, 2015 (Croft, 2012; Fonseca, 2015a).

The September 15 release of ISO 9001:2015 brought several significant changes compared to ISO 9001:2008 (Fonseca, 2015a):

- The adoption of a common high-level structure for all ISO Management System Standards (MSSs), with identical core text, terms, and definitions, to ensure compatibility and foster easier implementation and integrating of ISO MSS with the management systems of organizations.

- The ISO 9001:2008 concept of management responsibility has been replaced by leadership in ISO 9001:2015. The top management should lead and commit to the QMS and be strongly accountable for its effectiveness.

- There is a new ISO 9001:2015 requirement addressing the context of the organization, the internal and external issues that can impact the organizational strategic objectives and the planning of its QMS. Possible trends and changes in internal and external context and the relevant requirements of the relevant interested parties need to be monitored and reviewed and leading to the planning and implementation of QMS changes.

- Risk-based-thinking was included, replacing the so-called preventive actions in the 2008 edition of ISO 9001. The relevant risks and opportunities that may affect the QMS and its intended results must be identified and managed, both at the organizational and at the process level, emphasizing the systemic and systematic nature of prevention. 
- ISO 9001:2015 brings a reinforced focus on the process approach and the intended QMS results, with less emphasis on prescriptive requirements and documentation.

- Since improvement can be achieved both in a continual and in a disruptive mode, the concept of improvement replaced continual improvement allowing for both sorts of improvements.

- The consideration of change management and knowledge management have been introduced (both at strategic and the operational level) and the objectives to be achieved with the changes must be defined, and its implications and impacts, either positive or negative, identified, and managed. Moreover, the required resources and organizational knowledge need to be available, and the QMS integrity checked and ensured.

Numerous authors contributed to the debate of previous ISO 9000 standards revisions (Vouzas \& Gotzamani, 2005; van der Wiele, van Iwaarden, Brown, Steimle \& Zink, 2009) and ISO 9001:2015 caught researchers' attention. However, due to its novelty, few investigations have addressed its implementation. This is unfortunate, as the ISO 9001:2015 aims at embedding quality management on several organizational levels and linking QMS more with the overall strategy and the prevailing mindset of an organization. An implementation, therefore, affects an organization systemically and should subsequently be treated with appropriate management care and attention.

Fonseca (2015a) studied and compared the Draft DISO 9001:2015 version with Total Quality Management approaches concluding it is a step towards that direction and can represent significant benefits for the organizations, such as less emphasis on documentation and new/reinforced approaches. Chen, Anchecta, Lee and Dahlgaard (2016), presented a stepwise ISO-TQM implementation approach based on ISO 9001:2015 and Marques, Meyrelles, Saraiva and Frazão-Guerreiro (2016) proposed a model for integrating Lean and or Six Sigma projects by systematically linking with the applicable clauses and sub-clauses of ISO 9001:2015. Anttila and Jussila (2017) analyzed the ISO 9001:2015 International Standard and gathered feedback during the first six months of its application. They concluded that there are improvements in the ISO 9001 edition of 2015, such as the new harmonized structure, the adoption of risk-based thinking and the reinforced business-centered focus on business processes; however, they claim it is ambiguous, and it has incomplete and imperfect text and requirements.

There are also several empirical investigations addressing the implementation of ISO 9001:2015. Based on a survey among 393 IRCA registered auditors worldwide, Fonseca and Domingues (2017) posit that ISO 9001:2015 is in line with modern business and quality management concepts and will be a useful tool for organizations that successfully adopt this international standard. Based on an empirical study with 1,175 German companies, Rybski, Jochem and Homma (2017) concluded that there is a lack of training and knowledge concerning the new requirements of ISO 9001:2015, particularly regarding the adoption of risk-based thinking. Research also suggests that ISO 9001:2015 will require new approaches and competencies for quality and organizational excellence managers (Fonseca, Domingues \& Sá,, 2017) and auditors (Gluck et al., 2015). In a study with a sample of 28 CB experts and quality managers from European manufacturing SMEs, Chiarini (2017) identified the lack of competence regarding risk assessment as a significant challenge to ISO 9001:2015 implementation. Fonseca and Domingues (2018a), based on an empirical study of more than 300 Portuguese organizations, ISO 9001-certified or in the process of becoming certified, identified risk-based thinking, mapping of the organisational context, and stakeholder identification as the most relevant benefits reported for ISO 9001:2015. Additionally, they found evidence that ISO 9001:2015 enhances both internal and external organizational issues and generates benefits for all the researched dimensions. According to Hussain et al. (2018), based on a bibliometric analysis of ISO 9001 Elsevier Scopus Bibliometric database journal articles, published during 1987-2015 period, the findings are still inconclusive for issues like "the performance outcomes, challenges in acquiring, registering, and maintaining certification, lessons learned, and effectiveness of certification, internal and external challenges, and the trade-off between cost and benefits". These studies outline three main propositions: first, for some researchers, ISO 9001:2015 is in line with modern business and quality management concepts and will be a useful tool for organizations that successfully adopt this international standard and can be regarded as a step towards TQM; second, some authors acknowledge benefits through ISO 9001:2015 but also point to some shortcomings; third, there is a lack of awareness and training for the implementation of ISO 9001:2015 and some of its new requirements, e.g., risk-based approach.

Several researchers have highlighted the different challenges and practices of organizations in different regions of the world face while adopting ISO certification (Heras-Saizarbitoria \& Boiral, 2013; Nair \& Prajogo, 2009). There 
are also observed differences in the driving forces for ISO 9001 certification between manufacturing and services (Pekovic, 2010), hinting that the results of ISO 9001 certification may depend on the sector of activity of the organization. Another significant domain of ISO-based research is whether organizations size (number of employees) and turnover, influences the results of ISO 9001 certification, due to different resources availability and flexibility and openness for changes (Fonseca \& Domingues, 2018a).

This study aims to investigate if: 1) the methodology adopted by the organization concerning ISO 9001:2015 transition process; 2) the benefits achieved by successfully implementing ISO 9001:2015 requirements; 3) the difficulties the organization had to implement ISO 9001 successfully: 2015 requirements; and 4) the lessons learned with ISO 9001:2015 transition/certification requirements, differ according to the relevant variables reported in the literature:

- The country where the organization operates;

- The sector in which the organization operates;

- The size of the organization;

- The annual turnover of the organization.

In line with existing literature, this investigation aims to contribute to the ISO 9001:2015 body of knowledge by researching, within a multi-country perspective, the transition methodologies, difficulties, benefits, leading practices and the overall lessons learned with these processes for organizations in various sectors, countries and spanning a range of sizes. It is expected that these results, based on a considerable sample, can contribute to foster the successful implementation and certification of ISO 9001:2015, on a global scale.

\section{Research Methodology}

The research tool for this quantitative study was developed based on a literature review (e.g., Fonseca \& Lima, 2015; Fonseca \& Domingues, 2018a). It was pilot tested with the Swiss based IQNet - The International Certification Network, a network of leading certification bodies with worldwide coverage (IQNet, 2018) and the participating of CB IQNet partners experts from Portugal, Romania, Switzerland, and Turkey, leading to the approval of the final questionnaire. The construct reliability was tested and validated with Cronbach Alpha (greater than 0.7).

The survey was addressed to quality and organizational managers, and CEOs and the data was collected with an online questionnaire among ISO 9001:2015-certified organization from four CB partners of the leading IQNet network in Portugal, Romania, Switzerland, and Turkey. An e-mail was sent to the ISO 9001:2015-certified organizations in April 2018, and the answers were collected anonymously through an automated online database, until the end of April 2018.

The sample comprised a total of 7,260 organizations certified according to ISO 9001:2015. The overall response rate was 3.1\%, encompassing 222 organizations already certified according to ISO 9001:2015. While this is a lower response rate than those of national surveys, the overall sample size was considered sufficient to be representative and yield valuable research insights due to is large dimension and diversity, incorporating organizations of different sizes, sectors and geographical location. The survey was designed to include several sections as presented in Annex A. IBM Social Sciences Statistical Package (SPSS) v.22 software was used to conduct the statistical tests and calculations (after ordinal to a numerical transformation of the Likert scale type of answers). The non-parametric Kruskal-Wallis one-way analysis of statistical variance test was used to determine whether some variables, measured on an ordinal scale, differed significantly from other variables (namely those related to the characterization of the company). The survey results were monitored during the survey period to check for possible non-respondent bias with a "wave analysis" (Armstrong \& Overton, 1977). No significant differences were found between early and late respondents, and the analysis of the survey results suggests that it is representative since the distribution of the sample is consistent with the population, which minimizes possible bias errors.

The following research hypotheses were tested:

Dimension 1 - Methodology adopted by the organization concerning ISO 9001:2015 transition process 
Research Statement: The selection of the methodology adopted by the organization concerning the ISO 9001:2015 transition process differs with the ...

- Hypothesis 1 (H1) ... country where the organization operates.

- Hypothesis $2(\mathrm{H} 2) \ldots$ sector in which the organization operates.

- Hypothesis $3(\mathrm{H} 3) \ldots$ size of the organization.

- Hypothesis $4(\mathrm{H} 4)$... turnover of the organization.

Dimension 2 - The benefits the organization achieved by successfully implementing ISO 9001:2015 requirements

Research Statement: The benefits the organization achieved by successfully implementing ISO 9001:2015 requirements differ with the ...

- Hypothesis 5 (H5) ... country in which the organization operates.

- Hypothesis 6 (H6) ... sector in which the organization operates.

- Hypothesis 7 (H7) ... size of the organization.

- Hypothesis 8 (H8) ... turnover of the organization.

- Hypothesis 9 (H9) ... methodology adopted by the organization concerning the ISO 9001:2015 transition process.

Dimension 3 - The difficulties the organization had to successfully implement ISO 9001:2015 requirements

Research Statement: The difficulties the organization had to successfully implement ISO 9001:2015 requirements differ according to the ...

- Hypothesis 10 (H10) ... country where the organization operates.

- Hypothesis 11 (H11) ... sector in which the organization operates.

- Hypothesis 12 (H12) ... size of the organization.

- Hypothesis 13 (H13) ... turnover of the organization.

- Hypothesis 14 (H14) ... methodology adopted by the organization concerning the ISO 9001:2015 transition process.

Dimension 4 - The lessons learned with ISO 9001:2015 transition/certification requirements

Research Statement: The lessons learned with ISO 9001:2015 transition/certification requirements differ with the ...

- Hypothesis 15 (H15) ... country where the organization operates.

- Hypothesis 16 (H16) ... sector in which the organization operates.

- Hypothesis 17 (H17) ... size of the organization.

- Hypothesis 18 (H18) ... turnover of the organization.

- Hypothesis 19 (H19) ... methodology adopted by the organization concerning the ISO 9001:2015 transition process.

- Hypothesis 20 (H20) ... benefits the organization had to successfully implement ISO 9001:2015 requirements.

- Hypothesis 21 (H21) ... difficulties the organization had to successfully implement ISO 9001:2015 requirements.

The Kolmogorov-Smirnov and the Shapiro-Wilk statistical tests were used to evaluate the normality of the distribution of the results collected and as an indication for which tests to use subsequently for the research questions. The statistical tests show that the results did not have a normal distribution (Sigma $\leq 0.05)$ and therefore, the Kruskal-Wallis statistical test was used to ascertain and validate the statistical hypotheses formulated. Variable 2.2 was divided into five different dimensions (Table 1). 
To validate the research hypotheses $\mathrm{H} 5$ to $\mathrm{H} 21$, the following criteria were adopted per dimension of the survey:

- Hypothesis validated $(\checkmark)$ : at least $2 / 3$ of the items tested validated according to the Kruskal-Wallis test (p-value $<0.05)$.

- Hypothesis partially validated: More than $1 / 3$ and less than $2 / 3$ of the items tested validated according to the Kruskal-Wallis test ( $\mathrm{p}$-value $<0.05)$.

- Hypothesis rejected (x): Less than $1 / 3$ of the items tested validated according to the Kruskal-Wallis test (p-value $<0.05)$.

\begin{tabular}{|c|l|}
\hline Dimension & \multicolumn{1}{c|}{ Description } \\
\hline 1 & Timing when organizations started working in the transition process \\
\hline 2 & Perception of the 3-year transition process \\
\hline 3 & Activities carried out \\
\hline 4 & Perception of the information resources made available \\
\hline 5 & Adjustments performed on the existing management system \\
\hline
\end{tabular}

Table 1. Dimensions of Variable 2.2

\section{Findings}

\subsection{Profiles of Organizations/Respondents}

The quantitative survey yielded data on the traits of 222 organizations already certified according to ISO 9001:2015. Specifically, the survey detailed the role of respondents, their geographical context, sector, size, international orientation, and financial volume as well as the time since the last ISO 9001 certification. The characteristics of the surveyed respondents and their respective organizations are presented in Table 2.

\begin{tabular}{|c|c|c|c|}
\hline & & $\mathbf{n}$ & $\%$ \\
\hline \multirow{3}{*}{ Respondent's role } & Quality and organizational excellence managers & 141 & 65.3 \\
\hline & $\mathrm{CEO} / \mathrm{COO} / \mathrm{CFO}$ & 26 & 12.0 \\
\hline & Other & 49 & 22.7 \\
\hline \multirow{4}{*}{$\begin{array}{l}\text { Respondent's country } \\
\text { (geographical context) }\end{array}$} & Portugal & 50 & 23.1 \\
\hline & Switzerland & 62 & 28.7 \\
\hline & Turkey & 93 & 43.1 \\
\hline & Others & 11 & 5.1 \\
\hline \multirow{4}{*}{$\begin{array}{l}\text { Typology: number of } \\
\text { employees }\end{array}$} & Micro (less than 10) & 11 & 5.1 \\
\hline & Small $(11-50)$ & 61 & 28.2 \\
\hline & Medium (51-250) & 72 & 33.3 \\
\hline & Large & 72 & 33.3 \\
\hline \multirow{3}{*}{$\begin{array}{l}\text { International market } \\
\text { activity, in } \%\end{array}$} & $0 \%$ & 68 & 31.5 \\
\hline & Between 1 and 25\% & 80 & 37.0 \\
\hline & More than $25 \%$ & 68 & 31.5 \\
\hline \multirow{5}{*}{$\begin{array}{l}\text { Annual turnover in } \\
\text { Million Euros }\end{array}$} & Less than $0.5 \mathrm{M}$ & 32 & 14.8 \\
\hline & Between 0.5 and $5 \mathrm{M}$ & 57 & 26.4 \\
\hline & Between 5 and $10 \mathrm{M}$ & 32 & 14.8 \\
\hline & Between 10 and $50 \mathrm{M}$ & 42 & 19.4 \\
\hline & More than $50 \mathrm{M}$ & 53 & 24.5 \\
\hline \multirow{3}{*}{$\begin{array}{l}\text { Number of years of } \\
\text { ISO } 9001 \text { certification }\end{array}$} & Less than 3 & 42 & 19.4 \\
\hline & Between 3 and 6 & 18 & 8.3 \\
\hline & More than 6 & 156 & 72.2 \\
\hline
\end{tabular}




\begin{tabular}{|l|l|r|r|}
\hline \multirow{5}{*}{ Sector } & & n & \% \\
\hline \multirow{5}{*}{} & Industry & 80 & 37.0 \\
\cline { 2 - 4 } & Services and Commerce & 56 & 25.9 \\
\cline { 2 - 4 } & Health and Social & 27 & 12.5 \\
\cline { 2 - 4 } & Public Administration & 16 & 7.4 \\
\cline { 2 - 4 } & Others & 37 & 17.1 \\
\hline
\end{tabular}

Table 2. Characterization of respondents

\subsection{ISO 9001:2015 Transition Process}

The transition process was analyzed regarding timing and allowable time window for (re-)certification. Although almost half of the organizations (47.5\%) started to work with ISO 9001:2015 as late as 2017, only 3.9\% of the respondents considered the 3-year transition period (from September 15, 2015 to September 15, 2018) as too short.

The analysis of the transition process revealed several leading practices. Methodologically, 58.0\% of the respondents' organizations attended ISO 9001:2015 trainings and seminars, with 29.8\% relying solely on their own internal resources for the transition processes, while external consultants supported $22.7 \%$. Another $44.2 \%$ of the organizations gathered information from websites, newsletters, books, and interpretation guides, and certification bodies (CB) as major sources of valuable inputs (35.4\%). However, there was a split concerning the nature of the ISO 9001:2015 transition process information resources, with 25.4\% considering it as adequate, but 20.4\% stating it was too generic for guidance. Finally, 30.9\% of the organizations made significant adjustments to their existing ISO 9001:2008 QMS, while 28.2\% only made small ones. The percentages of respondents' answers concerning the adoption of ISO 9001:2015 transition process methodology is presented in Figure 1.

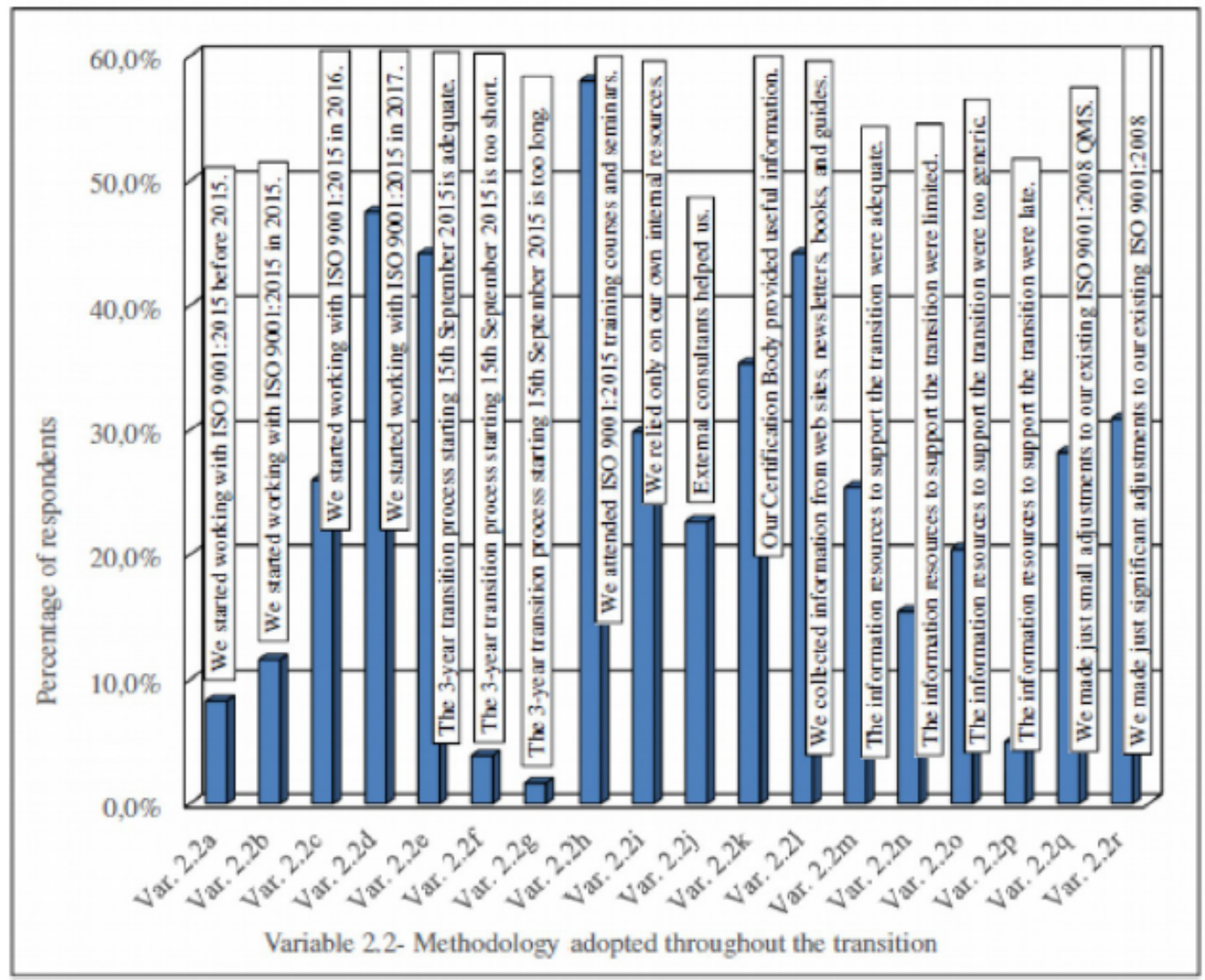

Figure 1. Methodology adopted by the organization concerning the ISO 9001:2015 transition process (\% of respondents) 
The data analysis yielded the most pertinent obstacles to the transition process. The adoption of risk-based thinking was reported as the major difficulty during the transition process (75.7\%), followed by the determination of the organizational context $(37.6 \%)$ and the identification of the relevant interested parties and their relevant requirements $(36.5 \%)$. Figure 2 presents the average values after ordinal to numerical transformation (scale: 1 minimum to 5 maximum) of the difficulties faced by the organization in the implementation of ISO 9001:2015.

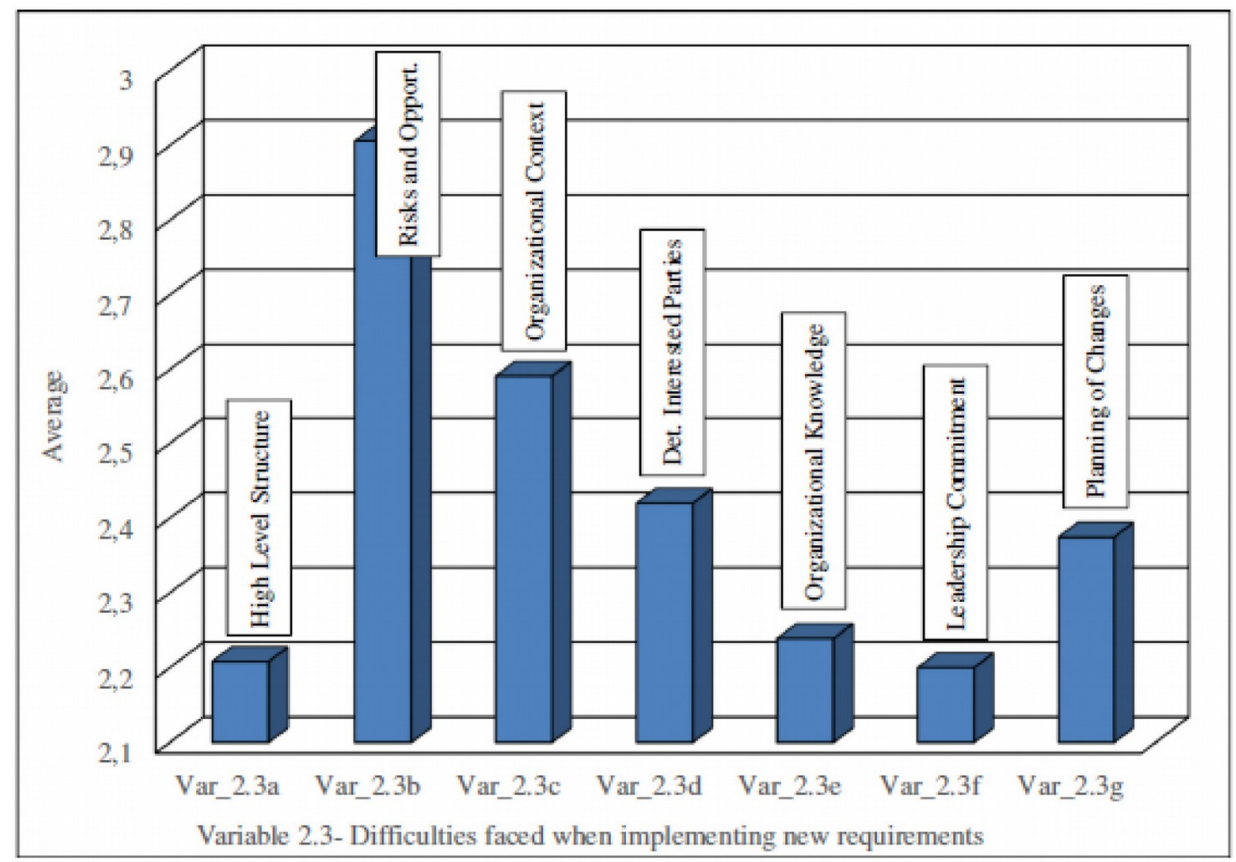

Figure 2. Average values of the difficulties faced by the organization when implementing the new ISO 9001:2015 requirements

\subsection{Benefits Achieved by ISO 9001:2015 Implementation}

The survey identified the most pertinent benefits of an implementation of ISO 9001:2015. With an average value of 4.17, the adoption of risk-based management was the major reported benefit achieved with an implementation of ISO 9001:2015, highlighting that the major obstacle also yields the most significant benefits. The alignment with other management systems (4.00), the increased top management commitment (3.90), the identification of risks and opportunities (3.93) and the knowledge management (3.83) were also mentioned as significant benefits of ISO 9001:2015. Conversely, it should be noted that cost reduction was evaluated as just 2.94 on a scale of 1 to 5 , hinting at a possible caveat of more time needed to quantify and achieve this desired outcome. Additionally, there were high variations in some reported benefits, such as documentation requirements (standard deviation of 1.20), cost reduction (standard deviation of 1.18) and improved integration with other MSSs (standard deviation of 1.13), which might be explained by different approaches used for the ISO 9001:2015 transition/certification processes (minor to significant adjustments) and their QMS maturity. Figures 3 and 4 present the averages and standard deviations of the benefits attained by the organizations with the implementation of the new ISO 9001:2015 requirements. 


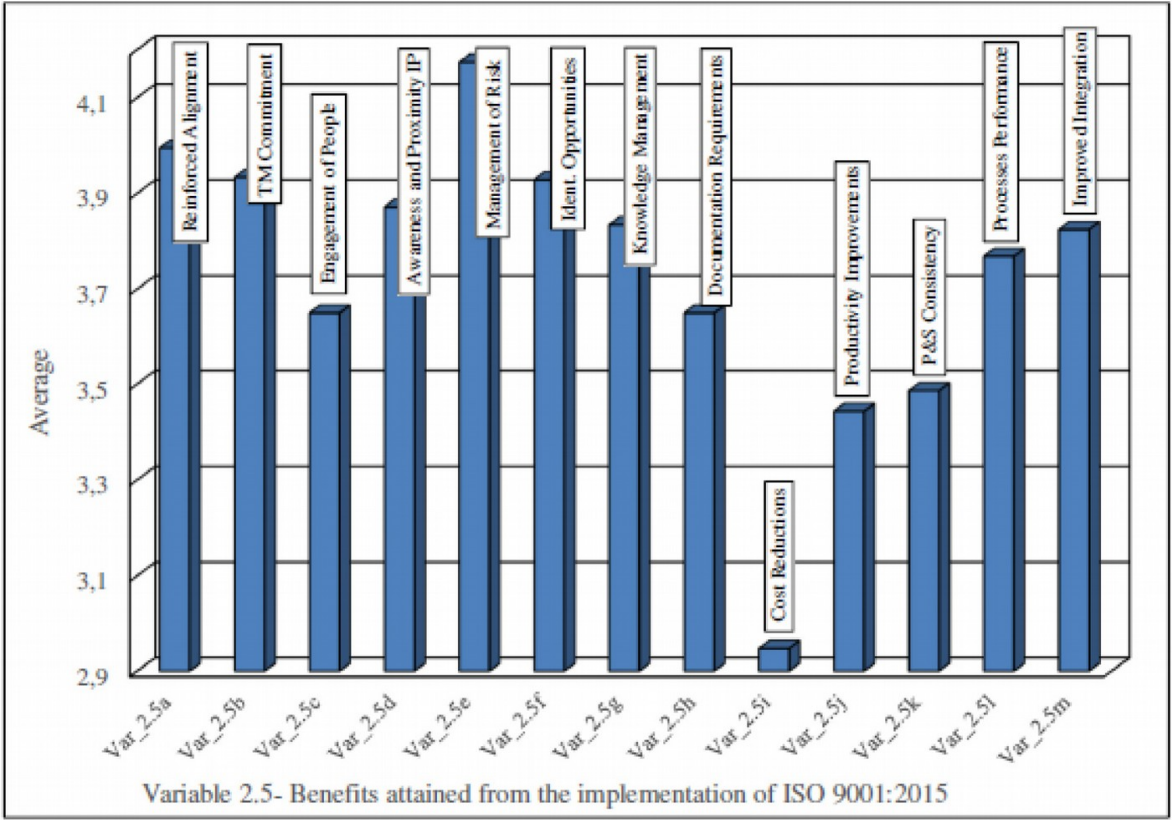

Figure 3. Average values of the benefits attained by the organization from the implementation of the new ISO 9001:2015 requirements

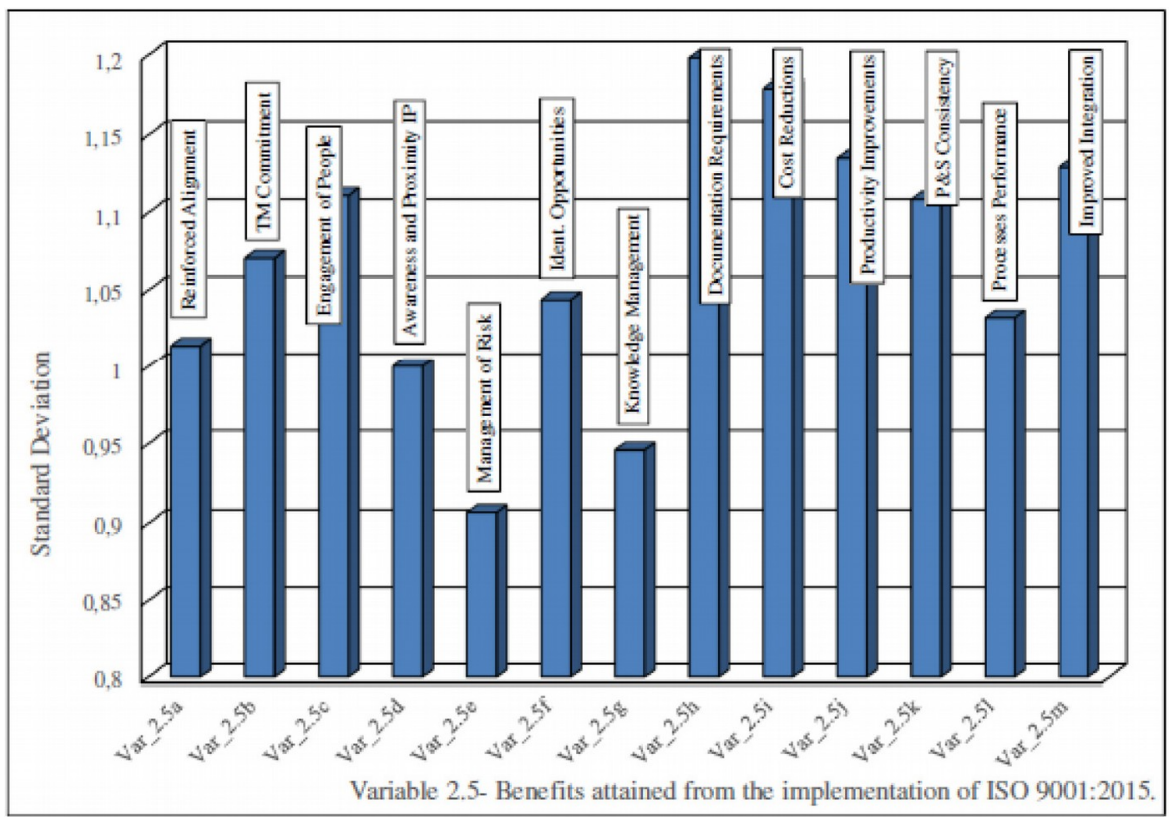

Figure 4. Standard deviations of the benefits attained by the organization fromthe implementation of the new ISO 9001:2015 requirements

\subsection{Lessons Learned from the ISO 9001:2015 Transition and Certification}

The lessons learned from the ISO 9001:2015 transition and certification by the respondents' organizations confirm that it was perceived as valuable to certify according to the ISO 9001:2015 edition (average 4.10) and consultants were helpful in that process (average 4.19). Some items showed a high variation among respondents, namely the support received from the certification body (standard deviation of 1.41), the value of training (standard deviation of 1.37) and the training effectiveness (standard deviation of 1.32). The detailed results of the lessons learned are presented in Figure 5 (averages) and Figure 6 (standard deviations). 


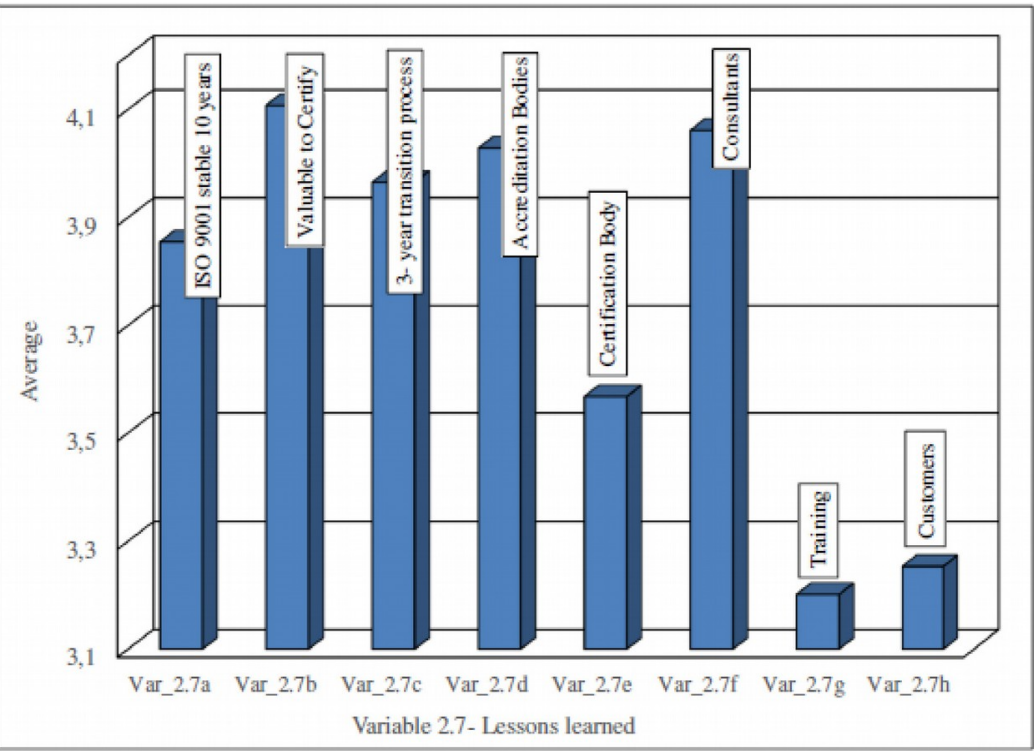

Figure 5. Average of the lessons learned with the implementation of the ISO 9001:2015 transition/certification requirements

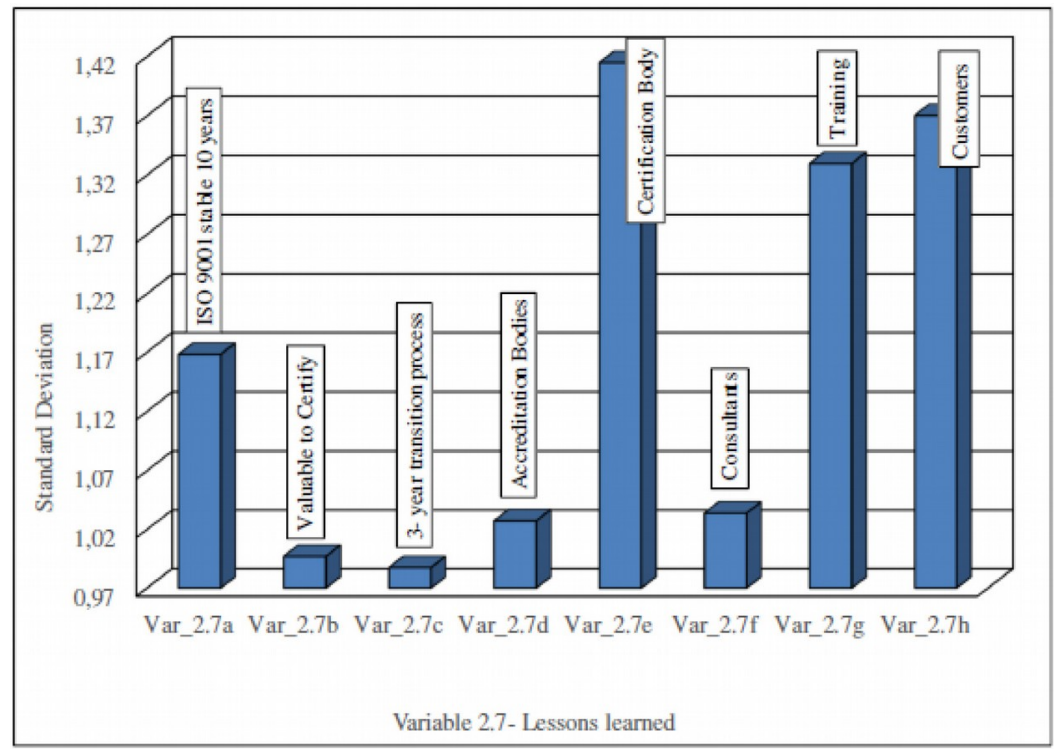

Figure 6. Standard deviation of the lessons learned with the implementation of the ISO 9001:2015 transition/certification requirements

To sum up, the new/reinforced ISO 9001:2015 approach reported as more beneficial was the "Adoption of risk-based thinking" (75.7\%), followed by "Organizational knowledge" (39.8\%), "Organizational context determination" (37.6\%) and "Identification of the relevant interested parties and their relevant requirements" (36.5\%). The overall results are presented in Figure 7.

There was a remarkable match with the significant difficulties previously reported (adoption of risk-based thinking, followed by the determination of the organizational context and the identification of the relevant interested parties and their relevant requirements), that highlight that requirements more challenging to implement were also those that yielded more benefits for the respondents' organizations. This conclusion is consistent with recent studies addressing the implementation of ISO 14001:2015 Environmental Management Systems (Fonseca \& Domingues, 2018b). 


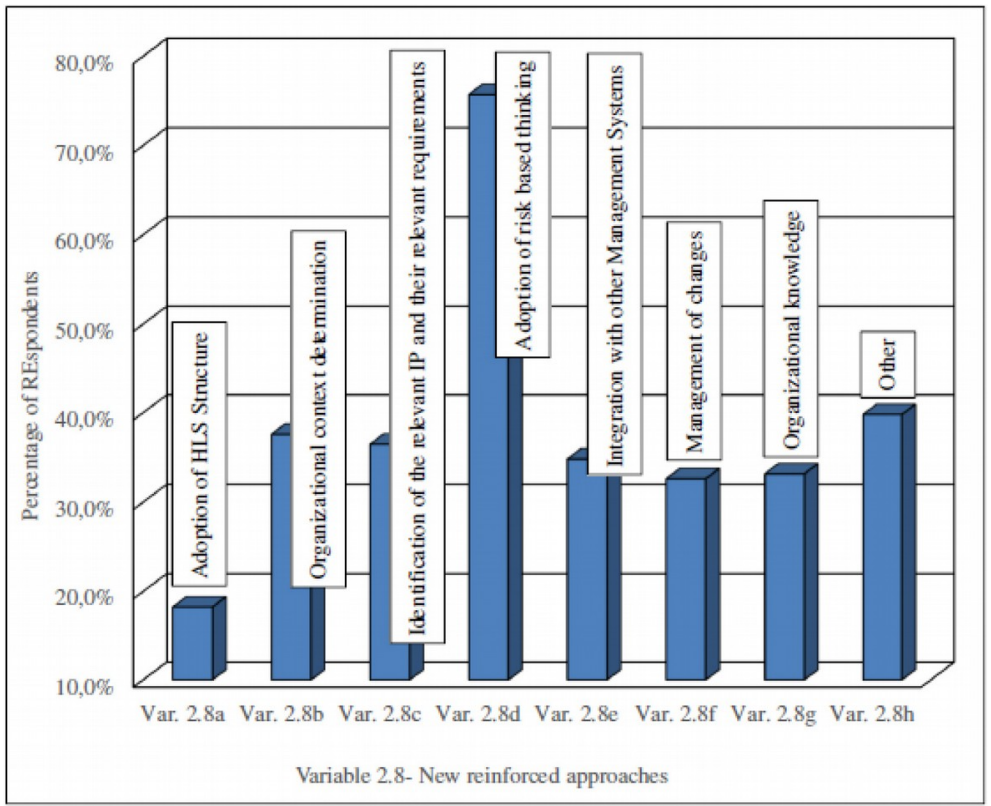

Figure 7. New/reinforced ISO 9001:2015 approaches considered more beneficial (\% of respondents)

\subsection{Results of the Hypotheses Testing}

Table 3 presents the results of the Kruskal-Wallis statistical test (Asymptotic Sigma) regarding the methodologies adopted. The results suggest that the initial timing, when organizations started working on the transition process, differed by country; namely, Turkey and Portugal started working on the transition process significantly later than Switzerland and other countries. Additionally, based on the statistical tests, the activities carried out seemed to differ by country and size of the organization. The "Other" country category displayed a strategy deviating from other countries: organizations within this category seem to have relied heavily upon their own resources and the support of external consultants compared to organizations from Turkey, Portugal, and Switzerland. On the other hand, employees from organizations of "Other" countries seem not to have attended as many ISO 9001:2015 trainings and seminars. Concerning the dimension of the organization, results suggest that micro-companies $(<10$ employees) favoured their internal resources compared to SMEs (between 11 and 250 employees) and large companies $(>250)$. On the other hand, SMEs and large companies seem to have collected a great deal of information by websites, newsletters, books, and interpretation guides.

The adjustments performed to the existing management systems seem to differ with the sector and size of the organization. Public administration and commerce and services made significant adjustments to the existing management systems, whereas health and social and other sectors introduced mainly slight adjustments. Regarding the industrial sector, the conclusions were not so straightforward. Regarding company dimension, it should be stated that micro-companies ( $<10$ employees) seem to have introduced solely slight adjustments compared to SMEs and large companies.

Concerning the validation of $\mathrm{H} 9$ (Table 4), some benefits attained by the organizations seem to differ with the perception of information resources made available (partially validated). Results suggest that organizations that rated the benefits "It promoted the engagement of the people throughout all organizational levels", "It raised awareness and proximity with relevant interested parties, their needs and expectations", "It improved awareness and allowed a more systematic approach to determine and manage risks", "Contributed to the Identification of opportunities", "It allowed for less prescriptive, and documentation requirements" and "We achieved cost reductions" higher also stated that information resources available were adequate (although limited and too generic) but did not find that these information resources were made available too late. Organizations that rated the benefit "It helped us to determine the knowledge needed, how to safeguard it and have access to it" lower also stated that 
information resources available were adequate although made available too late. Based on the collected data, no other validation was possible.

\begin{tabular}{|l|c|c|c|c|c|}
\hline \multicolumn{1}{|c|}{ Hypothesis } & Started Working & $\begin{array}{c}\text { Transition } \\
\text { Process }\end{array}$ & $\begin{array}{c}\text { Activities } \\
\text { Carried Out }\end{array}$ & $\begin{array}{c}\text { Information } \\
\text { Resources }\end{array}$ & Adjustments \\
\hline H1 Country & $0.001(\sqrt{ })^{* *}$ & $0.433(\mathbf{x})$ & $0.000(\mathbf{x})^{* * *}$ & $0.009(\sqrt{ })$ & $0.154(\mathbf{x})$ \\
\hline H2 Act. Sector & $0.652(\mathbf{x})$ & $0.212(\mathbf{x})$ & $0.237(\hat{\mathrm{u}})$ & $0.480(\mathbf{x})$ & $0.078(\mathbf{x})^{*}$ \\
\hline H3 Size Org. & $0.154(\mathbf{x})$ & $0.910(\mathbf{x})$ & $0.003(\sqrt{ }) * *$ & $0.324(\mathbf{x})$ & $0.013(\sqrt{ })^{* *}$ \\
\hline H4 Turnover & $0.304(\mathbf{x})$ & $0.283(\mathbf{x})$ & $0.123(\mathbf{x})$ & $0.503(\mathbf{x})$ & $0.245(\mathbf{x})$ \\
\hline
\end{tabular}

Hypothesis: validated $(\checkmark) *$ Statistical significant 0.1 level; ** Statistical significant at 0.05 level; *** Statistical significant at all levels; rejected $(\mathbf{x})$

Table 3. Asym. Sig. (Kruskal-Wallis test)

\begin{tabular}{|c|c|c|c|}
\hline \multirow{4}{*}{ Variable } & Dimension & $\begin{array}{c}\text { No. of statistically } \\
\text { significant benefits } \\
\text { (Var. 2.5) }(\mathrm{p}<0,1)\end{array}$ & Test validation result \\
\hline & Dimension 1 & 1 & $\mathbf{x}$ \\
\cline { 2 - 4 } Var. 2.2 & Dimension 2 & 1 & $\mathbf{x}$ \\
\cline { 2 - 4 } & Dimension 3 & 0 & $\mathbf{x}$ \\
\cline { 2 - 4 } & Dimension 4 & 7 & Partially Validated \\
\cline { 2 - 4 } & Dimension 5 & 0 & $\mathbf{x}$ \\
\hline
\end{tabular}

Hypothesis: validated $(\checkmark)$, partially validated, rejected $(\mathbf{x})$

Table 4. Hypothesis 9 validation

Concerning the validation of $\mathrm{H} 14$ (Table 5), some difficulties faced by organizations seem to differ with the initial timing when organizations started working on the transition process, the perception on information resources made available, and the adjustments made on the existing management system (partially validated). Generally, Organizations that rated the difficulties "Implementation of high-level structure", "Determination of risk and opportunities and the actions to address them", "Leadership commitment" and "Planning of changes" higher also made significant changes to the existing management system. Additionally, organizations that rated the difficulties "Implementation of high-level structure", "Determination of risk and opportunities and the actions to address them", "Organizational context determination - internal and external relevant issues" and "Determination of the relevant interested parties and their relevant requirements" higher also found information resources limited, too generic and made available too late. Organizations that rated the difficulties "Implementation of high-level structure", "Organizational context determination - internal and external relevant issues" and "Planning of changes" higher also started working with ISO 9001:2015 in 2016 and 2017. Based on the collected data, no other validation yielded significant results.

Concerning the validation of H14 (Table 6), the assessment of some lessons learned by the organizations throughout the transition process seems to differ with activities carried out (partially validated). The perceptions that the 3-year transition process was planned and managed in an effective way, that the certification body and consultants provided an effective support, and that the training was helpful differed with the activities carried out. Organizations that rated "The 3-year transition process was planned and managed in an effective way" and "Our Certification Body provided us with effective support" higher also attended ISO 9001:2015 training courses and seminars and stated that the certification bodies provided useful information. On the other hand, they did not have to collect as much information from websites, newsletters, books, and interpretation guides. Organizations that rated "Consultants provided us with effective support" and "Training was helpful" higher also stated that external 
consultants were helpful, they did not rely so heavily on their internal resources and did not collect so much information from websites, newsletters, books, and interpretation guides. Based on the collected data and according to the criteria applied, no other validation was possible.

\begin{tabular}{|l|l|c|c|}
\hline \multirow{4}{*}{ Variable } & Dimension & $\begin{array}{c}\text { No. of statistically } \\
\text { significant difficulties } \\
\text { (Var. 2.3) }(\mathrm{p}<0,1)\end{array}$ & Test validation result \\
\hline \multirow{4}{*}{ Var. 2.2 } & Dimension 1 & 3 & Partially \\
\cline { 2 - 4 } & Dimension 2 & 1 & $\mathbf{x}$ \\
\cline { 2 - 4 } & Dimension 3 & 1 & $\mathbf{x}$ \\
\cline { 2 - 4 } & Dimension 4 & 4 & Partially \\
\cline { 2 - 4 } & Dimension 5 & 4 & Partially \\
\hline
\end{tabular}

Hypothesis: validated $(\checkmark)$, partially validated, rejected $(\mathbf{x})$

Table 5. Hypothesis 14 validation

\begin{tabular}{|l|c|c|c|}
\hline \multirow{4}{*}{ Variable } & Dimension & $\begin{array}{c}\text { No. of statistically } \\
\text { significant lessons } \\
\text { learned (Var. 2.7) }(\mathrm{p}<0.1)\end{array}$ & Test validation result \\
\hline \multirow{4}{*}{ Var. 2.2 } & Dimension 1 & 1 & $\mathbf{x}$ \\
\cline { 2 - 4 } & Dimension 2 & 2 & $\mathbf{x}$ \\
\cline { 2 - 4 } & Dimension 3 & 4 & Partially \\
\cline { 2 - 4 } & Dimension 4 & 2 & $\mathbf{x}$ \\
\cline { 2 - 4 } & Dimension 5 & 0 & $\mathbf{x}$ \\
\hline
\end{tabular}

Hypothesis: validated $(\checkmark)$, partially validated, rejected $(\mathbf{x})$

Table 6. Hypothesis 19 validation

\section{Discussion and Research Implications}

The body of knowledge on ISO 9001 is continuously growing (Fonseca, Domingues, Machado et al., 2017); however, there is a clear research gap on the transition/certification process with the introduction of the revised ISO 9001:2015. This study presents the findings of a quantitative survey among 222 organizations and their experience with ISO 9001:2015. Major benefits, leading practices and lessons learned concerned mainly time allowed for transition, sources of information, and the adoption of risk-based thinking. The results indicate that there are some significant differences in the transition/certification process depending on the country and sector as well as the size of an organization.

There were some obvious differences in the transition/certification process between organizations from different countries. Many Swiss organizations started to work with ISO 9001:2015 earlier than organizations in other countries. Although almost half of the surveyed organizations (47.5\%) started to work with ISO 9001:2015 as late as 2017, only 3.9\% considered the 3-year transition period (from September 15, 2015, to September 15, 2018) as too short. This might help to explain and confirm some of the differences found in surveys conducted only on national levels and highlighted the importance of a timely introduction of changes to allow for organizational inertia in the transition to ISO 9001:2015.

The revision of ISO 9001:2015 requires adaptations in existing QMS. Methodologically, 58\% of the respondents' organizations attended ISO 9001:2015 trainings and seminars, with $29.8 \%$ relying solely on their own internal resources for the transition processes, while external consultants supported $22.7 \%$. Micro-companies relied more on their own internal resources compared to SMEs and large companies (that collected considerable information from websites, newsletters, books, and interpretation guides). Concerning the extent of the adjustments to the 
QMS for an adoption of ISO 9001:2015, there was a balance between organizations that made significant adjustments to their existing ISO 9001:2008 QMS (30.9\%) with those made only small ones $(28.2 \%)$. The sectors of public administration and commerce and services made significant adjustments in contrasts to micro-companies $(<10$ employees) that reported having introduced solely slight adjustments. Although most organizations reported a successful transition to ISO 9001:2015, more research is required to analyze if the adjustments made were improving or degrading the overall quality of the QMS of organizations and the specific role of external consultants as agents of change.

The revision of ISO 9001 triggered a need for information among organizations, on the content as well as on the changes necessary for a successful transition. Concerning the nature of information resources for the ISO 9001:2015 transition process, $25.4 \%$ considered it as adequate, but 20.4\% stated it was too generic for guidance, with the company that rated the benefits of ISO 9001:2015 adoption higher also judged the information resources as adequate, while those that rated the benefits lower also stated they were made available too late. The respondents' organizations emphasized that it was valuable to certify according to the ISO 9001:2015 edition and trainings and consultants were helpful in that process. The organizations that successfully managed the ISO 9001:2015 transition/certification process were the ones that attended ISO 9001:2015 training courses and seminars and got useful information from their CB. This approach can, therefore, be identified as leading practice and guidance for organizations intending to get certified.

The revision of ISO 9001:2015 is aiming at providing significant benefits in the current business context. The adoption of risk-based thinking was the major reported benefit achieved by the implementation of ISO 9001:2015, followed by the alignment with other management systems, the increased top management commitment, the identification of risks and opportunities and the knowledge management. With cost reduction evaluated at about 3 on a scale of 5, there seems to be a delay to achieve this desired outcome. Consistent with the ISO 9001:2015 literature, the realization of the major benefits requires more time and effort. The benefits attained by the organizations seem to differ with the perception of information resources made available, so the identification and promotion of the resources that led to the highest benefits are worth pursuing. Significant adjustments and the (less) availability of resources led to a large number of difficulties in the transition from the 2008 to the 2015 version of ISO 9001. Organizations that adopt early planning reported more major benefits and fewer difficulties, which is a significant lesson learned and can be labeled as leading practice. In conclusion, there is a perception of benefits from implementing ISO 9001; however, providing enough time is essential for realizing these.

Any transition/certification process involves obstacles that need to be overcome. The adoption of risk-based thinking was reported as the major difficulty faced during the transition process, followed by the determination of the organizational context and the identification of the relevant interested parties and their relevant requirements. Organizations that made significant changes to their MSs reported the greatest difficulties and the same was true to the late ISO 9001:2015 adopters. Therefore, there seems to be a relationship between the scope and start of the change and the adoption of the significant mindset promoted by ISO 9001:2015.

In summary, the research results confirm the relevance of the addition of new and reinforced requirements, such as risk-based thinking in the ISO 9001:2015 edition, and the need to acquire proper competencies on that regard, as outlined by Fonseca and Domingues (2017), Rybski, Jochem and Homma (2017) and Chiarini (2017). Additionally, there is support for the view that ISO 9001:2015 enhances both internal and external organizational issues and will be a useful tool for organizations that successfully adopt this international standard, which is consistent with previous research from Fonseca and Domingues (2017, 2018a). However, this investigation also identifies some shortcomings and lack of awareness and training for the implementation of ISO 9001:2015, as reported by other researchers (Rybski, Jochem \& Homma, 2017; Chiarini, 2017).

There are several theoretical and practical implications of this investigation. Concerning the methodological aspects, an early start of the transitioning process can be strongly advised. Since the initial timing when organizations started working on the transition process and the activities carried out differed by country, the geographical context should be considered when planning transition processes and for future research on ISO 9001:2015. Moreover, it might be justified to instruct certification bodies in lagging countries to urge organizations for a timely onset of the change with future revisions of ISO 9001. Organizing the change is closely related to the 
activities carried out and the adjustments made to existing QMS, so this is another dimension to be considered. It can be derived that mandating external consultants is linked to the size of an organization. This further entails that it may be advisable to provide more information resources specifically geared for SME to facilitate the transition process. Moreover, national certification bodies should review their strategies to lower the threshold to be contacted by SME on information and issues of the transition/certification process.

The adjustments performed to the existing management systems seem to differ by sector. Similarly, the lessons learned by the organizations throughout the transition process seem to vary with the activities carried out, and activities should be carried out considering the context and sector, in which the organization operates as this will likely improve the efficiency of the transition process. Furthermore, future research should try and assess the quality of those adjustments, i.e., use longitudinal studies to monitor the maturity of organizations regarding the development of their QMS. The determinants of a "slight adjustment" and those of a "significant adjustment" should then be mapped, e.g., with case studies based on sector and maturity of the QMS. Thus, standardized roadmaps for the transition process of QMS could be designed and customized for organizations from different countries and sectors as well as along a scope of sizes.

This study is a first investigation to provide details on the transition/certification process of the revised ISO 9001:2015, encompassing several countries and sectors and a spectrum of diverse organizations. Although differences in perceived benefits, obstacles, leading practices, and lessons learned are significant, a replication of this study at a later stage and countries not considered in this research may contribute additional time and geographic perspectives to evaluate if these perceptions materialize into tangible results such as cost benefits and higher customer satisfaction.

\section{Declaration of Conflicting Interests}

The authors declared no potential conflicts of interest with respect to the research, authorship, and/or publication of this article.

\section{Funding}

Authors would like to thank all the organizations that kindly answered the questionnaire, to IQNet certification network and the IQNet CBs that provided the ISO 9001.2015 certified organization contacts for this investigation. CIDEM, R\&D unit is funded by the FCT-Portuguese Foundation for the Development of Science and Technology, Ministry of Science, Technology, and Higher Education, under the Project UID/EMS/0615/2016. Pedro Domingues benefited from financial support through the FCT post-doc research grant No. SFRH/BPD/103322/2014.

\section{References}

Armstrong, J.S., \& Overton, T.S. (1977). Estimating nonresponse bias in mail surveys. Journal of Marketing, 14(3), 396-402. https://doi.org/10.1177/002224377701400320

Anttila, J., \& Jussila, K. (2017). ISO 9001:2015 - a questionable reform. What should the implementing organisations understand and do? Total Quality Management and Business Excellence, 28(9-10), 1090-1105. https://doi.org/10.1080/14783363.2017.1309119

Boiral, O. (2012). ISO 9000 and organizational effectiveness: a systematic review. Quality Management Journal, 19(3), 16-37. https://doi.org/10.1080/10686967.2012.11918071

Bounabri, N., El Oumri, A.A., Saad, E., Zerrouk, L., \& Ibnlfassi, A. (2018). Barriers to ISO 9001 implementation in Moroccan organizations: empirical study. Journal of Industrial Engineering and Management, 11(1), 34-56. https://doi.org/10.3926/jiem.2412

Cagnazzo, L., Taticchi, P., \& Fuiano, F. (2010). Benefits, barriers and pitfalls coming from the ISO 9000 implementation: the impact on business performances. WSEAS Transactions on Business and Economics, 7(4), 311-321. 
Casadesús, M., \& Giménez, G. (2000). The benefits of the implementation of the ISO 9000 standard: empirical research in 288 Spanish companies. TQM Magazine, 12(6), 432-441. https://doi.org/10.1108/09544780010351751

Chatzoglou, P., Chatzoudes, D., \& Kipraios, N. (2015). The impact of ISO 9000 certification on firms' financial performance. International Journal of Operations and Production Management, 35 (1), 145-174.

https://doi.org/10.1108/IJOPM-07-2012-0387

Chen, C.K., Anchecta, K., Lee, Y.D. \& Dahlgaard, J.J. (2016). A stepwise ISO-based TQM implementation approach using ISO 9001:2015. Management and Production Engineering Review, 7(4), 65-75. https://doi.org/10.1515/mper-2016-0037

Chiarini, A. (2017). Risk-based thinking according to ISO 9001:2015 standard and the risk sources European manufacturing SMEs intend to manage. The TQM Journal, 29 (2), 310-323. https://doi.org/10.1108/TQM-04-20160038

Clougherty, J.A., \& Grajek, M. (2008). The impact of ISO 9000 diffusion on trade and FDI: a new institutional analysis. Journal of International Business Studies, 39(4), 613-633. https://doi.org/10.1057/palgrave.jibs.8400368

Corbett, C.J., Montes-Sancho, M.J., \& Kirsch, D.A. (2005). The financial impact of ISO 9000 certification in the United States: an empirical analysis. Management Science. 51, 1046-1059. https://doi.org/10.1287/mnsc.1040.0358

Croft, N.H. (2012). ISO 9001:2015 and beyond - Preparing for the next 25 years of quality management standards. ISO Focus +, 36 (online). Available at: http://www.iso.org/iso/news.htm?refid=Ref1633 (Accessed: February 2018).

Fonseca, L.M. (2015a). From quality gurus and TQM to ISO 9001:2015: a review of several quality paths. International Journal for Quality Research, 9(1), 167-180.

Fonseca, L.M. (2015b). Relationship between ISO 9001 certification maturity and EFQM business excellence model results. Quality, Innovation and Prosperity, 19(1), 85-102.

Fonseca, L.M., \& Lima, V.M. (2015). Impact of supplier management strategies on the organizational performance of ISO 9001 certified organizations. Quality Innovation Prosperity, 19(2), 32-54. https://doi.org/10.12776/qip.v19i2.592

Fonseca, L., \& Domingues, J.P.T. (2017). ISO 9001:2015 - Quality, management, and value. International Journal for Quality Research, 11(1), 149-158.

Fonseca, L.M., Domingues, J.P., Machado, P.B., \& Calderón, M. (2017). Management system certification benefits: where do we stand? Journal of Industrial Engineering and Management, 10(3), 476-494.

https://doi.org/10.3926/jiem.2350

Fonseca, L.M., Domingues, J.P., \& dos Guimarães Sá, J. (2017). Leading quality in the 21st century: Profiles of quality and organizational excellence managers. Quality - Access to Success, 18(161), 34-38.

Fonseca, L.M., \& Domingues, J.P. (2018a). Empirical research of the ISO 9001:2015 transition process in Portugal: Motivations, benefits, and success factors. Quality Innovation Prosperity / Kvalita Inovácia Prosperita, 22(2), $16-64$.

Fonseca, L.M., \& Domingues, J.P. (2018b). Exploratory research of ISO 14001:2015 transition among Portuguese organizations. Sustainability, 10, 781. https://doi.org/10.3390/su10030781

Georgiev, S., \& Georgiev, E. (2015). Motivational factors for the adoption of ISO 9001 standards in Eastern Europe: the case of Bulgaria. Journal of Industrial Engineering and Management, 8(3), 1020-1050. https://doi.org/10.3926/jiem.1355

Gluck, A., Aston, B., Briggs, S., Cianfrani, C., Desai, D., Palmes, P., et al. (2015). Keep calm and prepare for ISO 9001:2015. Quality Progress, September, 19-28.

Han, S.B., \& Chen, S.K. (2007). Effects of ISO 9000 on customer satisfaction. International Journal of Productivity and Quality Management, 2(2), 208-220. https://doi.org/10.1504/IJPQM.2007.012411 
Heras-Saizarbitoria, I., Arana, G., \& Boiral, O. (2015). Do ISO 9001-certified hotels get a higher customer rating than non-certified ones?. International Journal of Hospitality Management, 51,138-146.

https://doi.org/10.1016/j.ijhm.2015.08.006

Heras-Saizarbitoria, I., \& Boiral, O. (2013). ISO 9001 and ISO 14001: towards a research agenda on management system standards. International Journal of Management Reviews, 15(1), 47-65. https://doi.org/10.1111/j.14682370.2012.00334.x

Hussain, T., Eskildsen, J.K. \& Edgeman, R. (2018). The intellectual structure of research in ISO 9000 standard series (1987-2015): a bibliometric analysis. Total Quality Management \&o Business Excellence.

https://doi.org/10.1080/14783363.2018.1469977

IAF (2017). LAF Communiqué concerning LAF Resolution 2017-13 (online). Available at: http://www.iaf.nu/upFiles/IAF communique Important information for Certification Bodies regarding transition $\mathrm{t}$ o ISO 9001 and ISO 14001.pdf (Accessed: May 2018).

IQNet (2018) (online). Available at: http://www.iqnet-certification.com/index.php (Accessed: October 2018).

ISO (2008). ISO 9001 quality management systems - requirements. Geneva: International Organization for Standardization.

ISO (2015). ISO 9001 quality management systems - requirements. Geneva: International Organization for Standardization.

ISO (2018). ISO Survey 2017 (online). Available at: http//www.iso.org [Accessed 2018/09/05].

Jain, S.K., \& Ahuja, I.S. (2012). An evaluation of ISO 9000 initiatives in Indian industry for enhanced manufacturing performance. International Journal of Productivity and Performance Management, 61(7), 778-804. https://doi.org/10.1108/17410401211263863

Karapetrovic, S., Casadesús-Fa, M., Heras-Saizarbitoria, I. (2010). What happened to the ISO 9000 lustre? An eight-year study. Total Quality Management. 21(3), 245-267. https:/ / doi.org/10.1080/14783360903553149

Lo, C.K.Y., Yeung, A.C.L., \& Cheng, T.C.E. (2009). ISO 9000 and supply chain efficiency: empirical evidence on inventory and account receivable days. International Journal of Production Economics, 18, 367-374.

https://doi.org/10.1016/j.ijpe.2008.11.010

Marques, P.A., Meyrelles, P.M., Saraiva, P.M., \& Frazão-Guerreiro, F.J. (2016). Integrating Lean Six Sigma with ISO 9001:2015. In proceedings of the 2016 IEEE IEEM (894-898). https:/ / doi.org/10.1109/IEEM.2016.7798006

Martínez-Costa, M., \& Martínez-Lorente, A.R. (2007). A triple analysis of ISO 9000 effects on company performance. International Journal of Productivity and Performance Management, 56(5-6), 484-499. https://doi.org/10.1108/17410400710757150

Martínez-Costa, M., Martínez-Lorente, A.R., \& Choi, T.Y. (2008). Simultaneous consideration of TQM and ISO 9000 on performance and motivation: an empirical study of Spanish companies. International Journal of Production Economics, 113(1), 23-39. https://doi.org/10.1016/j.ijpe.2007.02.046

Nair, A., \& Prajogo, D. (2009). Internalisation of ISO 9000 standards: The antecedent role of functionalist and institutionalist drivers and performance implications. International Journal of Production Research, 47(16), 4545-4568. https://doi.org/10.1080/00207540701871069

O’Neill, P., Sohal, A., \& Teng, C.H. (2016). Quality management approaches and their impact on firms' financial performance - An Australian study. International Journal of Production Economics, 171, 381-393. https://doi.org/10.1016/j.ijpe.2015.07.015

Pekovic, S. (2010). The determinants of ISO 9000 certification: A comparison of the manufacturing and service sectors. Journal of Economic Issues (e-journal), 54(4), 895-914. https://doi.org/10.2753/JEI0021-3624440403

Phan, A.C., Abdallah, A.B., \& Matsui, Y. (2011). Quality management practices and competitive performance: empirical evidence from Japanese manufacturing companies. International Journal of Production Economics, 133 , 518-529. https://doi.org/10.1016/j.ijpe.2011.01.024 
Poksinska, B., Eklund, J., Jörn, D., \& Jens, J. (2006). ISO 9001:2000 in small organizations. The International Journal of Quality \& Reliability Management, 23(5), 490-512. https://doi.org/10.1108/02656710610664578

Prajogo, D.I. (2011). The roles of firms' motives in affecting the outcomes of ISO 9000 adoption. International Journal of Operations and Production Management, 31(1), 78-100. https://doi.org/10.1108/01443571111098753

Psomas, E.L., \& Fotopoulos, C.V. (2009). A meta-analysis of ISO 9001:2000 research - findings and future research proposals. International Journal of Quality and Service Sciences, 1(2), 128-144.

https://doi.org/10.1108/17566690910971418

Rodríguez-Escobar, J.A., Gonzalez-Benito, J., \& Martínez-Lorente, A.R. (2006). An analysis of the degree of small companies' dissatisfaction with ISO 9000 certification. Total Quality Management and Business Excellence, 17(4), 507-521. https://doi.org/10.1080/14783360500528304

Rybski, C., Jochem, R. \& Homma, L. (2017). Empirical study on status of preparation for ISO 9001:2015. Total Quality Management \& Business Excellence. https://doi.org/10.1080/14783363.2017.1303886

Santos, G., Costa, B., \& Leal, A. (2014). Motivation and benefits of implementation and certification according ISO 9001 - the Portuguese experience. International Journal of Engineering, Science and Technology, 6(5), 1-12. https://doi.org/10.4314/ijest.v6i5.1

Sharma, D.S. (2005). The association between ISO 9000 certification and financial performance. International Journal of Accounting, 40(2), 151-172. https://doi.org/10.1016/j.intacc.2005.01.011

Singh, P.J. (2008). Empirical assessment of ISO 9000 related management practices and performance relationships. International Journal of Production Economics, 113(1), 40-59. https:// doi.org/10.1016/j.ijpe.2007.02.047

Tarí, J.J., Molina-Azorín, J.F., \& Heras, I., (2012). Benefits of the ISO 9001 and ISO 14001 standards: a literature review. Journal of Industrial Engineering and Management, 5(2), 297-322. https://doi.org/10.3926/jiem.488

Terlaak, A. (2007). Order without law? The role of certified management standards in shaping socially desired firm behaviors. Academy of Management Review, 32(3), 968-985. https://doi.org/10.5465/AMR.2007.25275685

van der Wiele, T., van Iwaarden, J., Brown, A., Steimle, U., \& Zink, K.J. (2009). An international comparison of the perceptions about the revised ISO 9000 quality system standards. Total Quality Management and Business Excellence, 20(4), 393-408. https://doi.org/10.1080/14783360902781840

Vouzas, F.K., \& Gotzamani, K.D. (2005). Best practices of selected Greek organizations on their road to business excellence: the contribution of the new ISO 9000:2000 series of standards. TQM Magazine, 17(3), 259-266. https://doi.org/10.1108/09544780510594225

Yahya, S., \& Goh, W. K. (2001). The implementation of an ISO 9000 quality system. International Journal of Quality and Reliability Management, 18(9), 941-966. https://doi.org/10.1108/02656710110407127

Zimon, D. (2016). Influence of quality management system on improving process in small and medium-sized organizations. Quality - Access to Success, 17 (150), 61-64. 


\section{Annex A: Survey}

\section{Socio-demographic characterization of respondents}

We would like to begin with some background about you, your organization (the entity you work for) and its ISO 9001:2015 status. So, please select ...:

1.1. Country (select from list):

1.2. ... the activity sector of the organization (choose the one that better describes it):

1.3. ... the number of employees of your organization:

1.4. ... the percentage of activity in the international market:

1.5. ... the annual turnover (in US\$) of your organization:

1.6. ... the number of sites of your organization:

1.7. Is your organization certified according the 2015 revision?

\section{ISO 9001:2015- Certified Organizations}

\subsection{Please select the first year of ISO 9001 certification:}

2.2. Please choose the options that best describe the methodology adopted by your organization concerning the ISO 9001:2015 transition process:

$\square$ We started working with ISO 9001:2015 before 2015.

$\square$ We started working with ISO 9001:2015 in 2015.

$\square$ We started working with ISO 9001:2015 in 2016.

口 We started working with ISO 9001:2015 in 2017.

$\square$ The 3-year transition process starting 15th September 2015 is adequate.

$\square$ The 3-year transition process starting 15th September 2015 is too short.

$\square$ The 3-year transition process starting 15th September 2015 is too long.

$\square$ We attended ISO 9001:2015 training courses and seminars.

$\square$ We relied only on our own internal resources.

$\square$ External consultants helped us.

$\square$ Our Certification Body provided useful information.

$\square$ We collected information from web sites, newsletters, books, and interpretation guides.

$\square$ The information resources to support the ISO 9001:2015 transition processes were adequate.

$\square$ The information resources to support the ISO 9001:2015 transition processes were limited.

$\square$ The information resources to support the ISO 9001:2015 transition.

$\square$ processes were too generic for guidance.

$\square$ The information resources to support the ISO 9001:2015 transition.

$\square$ processes were made available too late.

$\square$ We made just small adjustments to our existing ISO 9001:2008 Quality

$\square$ Management System.

$\square$ We made significant adjustments to our existing ISO 9001:2008 Quality Management System.

2.3. To which extent did your organization had difficulties to successfully implement the following ISO 9001:2015 requirements: 


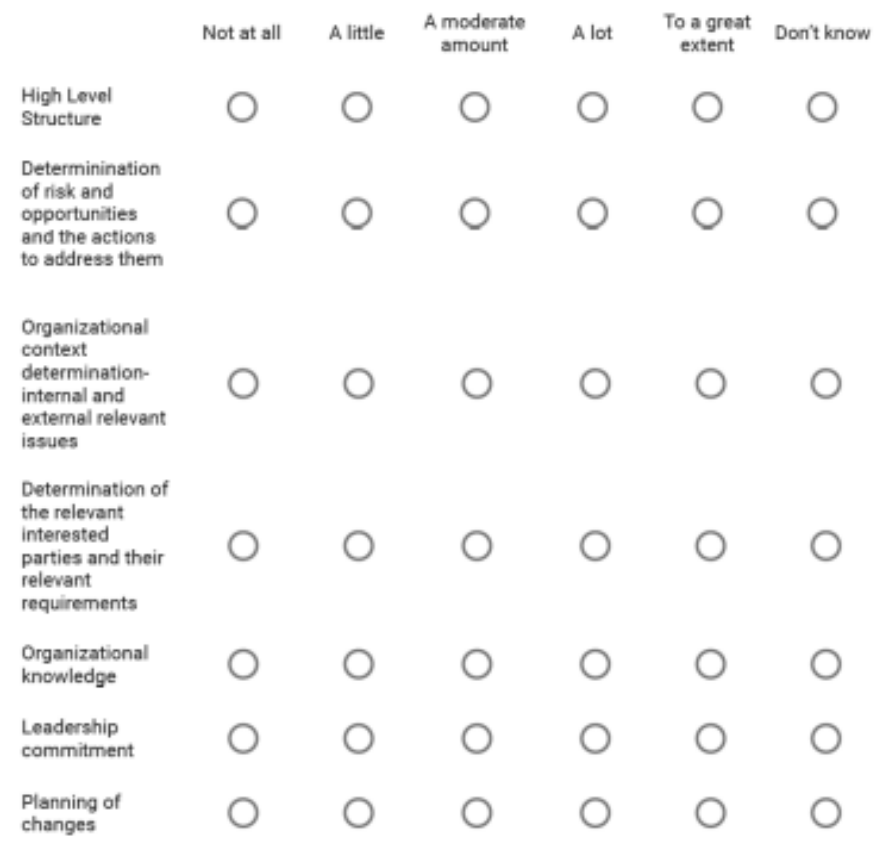

2.4. Please point out any other significant difficulty (please specify):

2.5. Concerning the benefits that your organization achieved by successfully implementing ISO 9001:2015 requirements, or expects to achieve in the near future, to which extent do you agree with the following statements?

Strongly
disagree $\begin{aligned} & \text { Somewhat } \\ & \text { disagree }\end{aligned}$




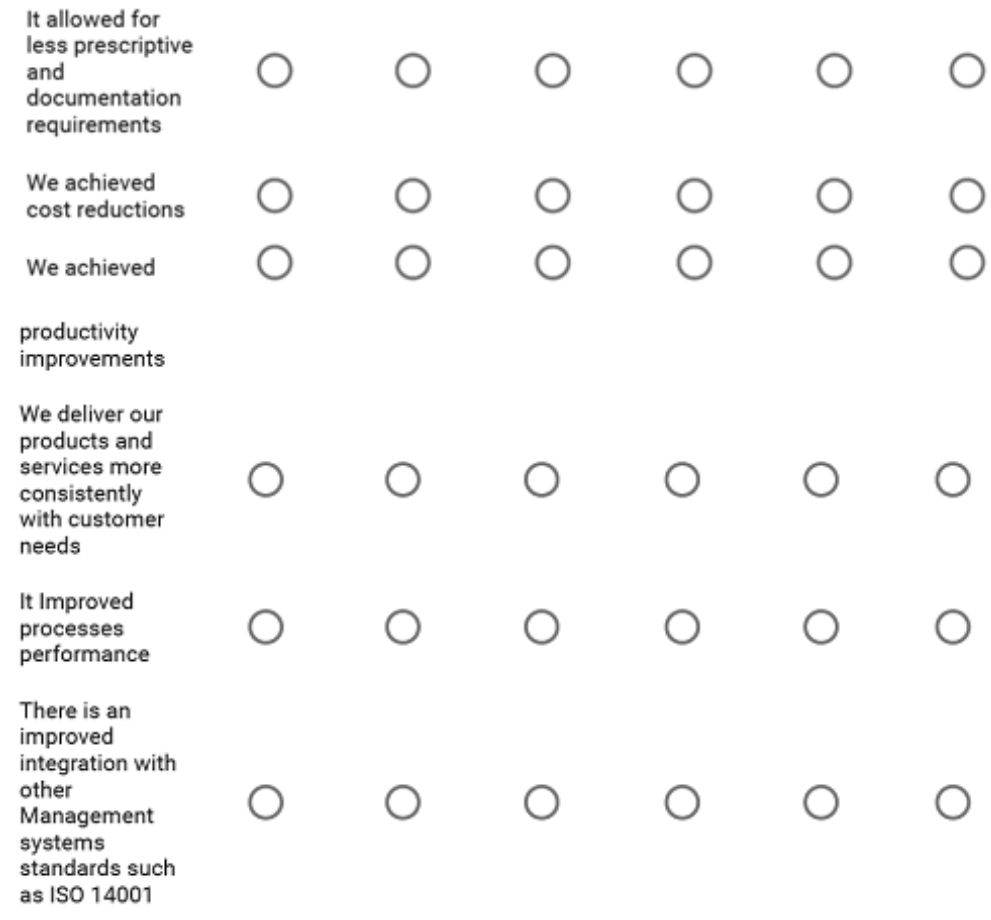

2.6. Please point out any other significant benefit (please specify):

2.7- Concerning the lessons learned with ISO 9001:2015 transition/certification requirements, to which extent do you agree with the following statements?

\begin{tabular}{|c|c|c|c|c|c|c|}
\hline & $\begin{array}{l}\text { Strongly } \\
\text { disagree }\end{array}$ & $\begin{array}{c}\text { Somewhat } \\
\text { disagree }\end{array}$ & $\begin{array}{l}\text { Neither } \\
\text { agree nor } \\
\text { disagree }\end{array}$ & $\begin{array}{c}\text { Somewhat } \\
\text { agree }\end{array}$ & $\begin{array}{l}\text { Strongly } \\
\text { Agree }\end{array}$ & Dont know \\
\hline $\begin{array}{l}\text { ISO } 9001: 2015 \\
\text { will remain } \\
\text { updated and } \\
\text { stable for the } \\
\text { next } 10 \text { years }\end{array}$ & 0 & 0 & 0 & 0 & 0 & 0 \\
\hline $\begin{array}{l}\text { It was valuable to } \\
\text { transition/certify } \\
\text { with ISO } \\
900112015\end{array}$ & $\mathrm{O}$ & 0 & 0 & 0 & 0 & 0 \\
\hline $\begin{array}{l}\text { The 3-year } \\
\text { transition } \\
\text { process was } \\
\text { planned and } \\
\text { managed in an } \\
\text { effective way }\end{array}$ & 0 & 0 & 0 & 0 & 0 & 0 \\
\hline $\begin{array}{l}\text { Our Certification } \\
\text { Body provided us } \\
\text { with effective } \\
\text { support }\end{array}$ & $\mathrm{O}$ & 0 & $\mathrm{O}$ & 0 & 0 & 0 \\
\hline $\begin{array}{l}\text { Consultants } \\
\text { provided us with } \\
\text { effective support }\end{array}$ & $\mathrm{O}$ & $\mathrm{O}$ & $\mathrm{O}$ & 0 & 0 & 0 \\
\hline $\begin{array}{l}\text { Training was } \\
\text { helpful }\end{array}$ & 0 & 0 & 0 & 0 & 0 & 0 \\
\hline $\begin{array}{l}\text { Our organization } \\
\text { involved its } \\
\text { customers in the } \\
\text { ISO 9001:2015 } \\
\text { transition } \\
\text { process }\end{array}$ & 0 & 0 & 0 & 0 & 0 & 0 \\
\hline $\begin{array}{l}\text { Our organization } \\
\text { involved its } \\
\text { services } \\
\text { providers in the } \\
\text { iso } 9001: 2015 \\
\text { transition } \\
\text { process }\end{array}$ & $\mathrm{O}$ & 0 & $\mathrm{O}$ & 0 & 0 & 0 \\
\hline
\end{tabular}


2.8. Which were the new/reinforced ISO 9001:2015 approaches that your organization considers more beneficial?

$\square$ Adoption of HLS Structure

$\square$ Organizational context determination

$\square$ Identification of the relevant interested parties and their relevant requirements

$\square$ Adoption of risk-based thinking

$\square$ Integration with other Management Systems

$\square$ Management of changes

$\square$ Organizational knowledge

$\square$ Other

\section{Role of Respondent}

$\square \mathrm{CEO}$ (Chief Executive Officer)/ General Manager

$\square \mathrm{COO}$ (Chief Operational Officer)/ Operations Manager

$\square \mathrm{CFO}$ (Chief Financial Officer)/Financial Manager

$\square$ Quality and/or Organizational Excellence Manager

$\square$ Manager

$\square$ Expert / Specialist

$\square$ Assistant

$\square$ Other

\section{Thank you very much!}

Please press "Submit".

Journal of Industrial Engineering and Management, 2019 (www.jiem.org)

\section{(c) $(1)(9)$}

Article's contents are provided on an Attribution-Non Commercial 4.0 Creative commons International License. Readers are allowed to copy, distribute and communicate article's contents, provided the author's and Journal of Industrial Engineering and Management's names are included. It must not be used for commercial purposes. To see the complete license contents, please visit https://creativecommons.org/licenses/by-nc/4.0/. 